\title{
MENINGOENCEFALITE NECROSUPURATIVA SECUNDÁRIA POR OTITE INTERNA EM UM CANINO - RELATO DE CASO
}

\author{
(Secondary necrosupurative meningoencephalitis due to internal otitis in a canine - case report)
}

Joana Cristina Smaha de Jesus Lima, Karim Cristhine Pase Montagnini, Carolina Fontana, Juliana das Chagas Goulart, Arthur Colombari Cheng, Estela Dall'Agnol Gianezini, Nicolle Glaeser Pelosi, Aline de Marco Viott

Universidade Federal do Paraná, Palotina, Paraná, Brasil.

*Correspondência: joanacristinasmaha@gmail.com

RESUMO: A otite interna é a inflamação do ouvido interno, geralmente por extensão das otites médias. As causas bacterianas são as mais comuns e uma das complicações da otite interna, principalmente do tipo supurada, é a meningoencefalite, decorrente da proximidade do encéfalo com o ouvido interno (SANTOS \& ALESSI, 2016). Diante disto, relata-se um caso de meningoencefalite causada por otite média em um canino assim como os achados clínicos e patológicos evidenciados. Foi atendido no Hospital Veterinário, um canino, macho, labrador, sem informe de idade, que apresentava há duas semanas head tilt, meneios cefálicos e paresia. No exame físico, constatou-se otite média e interna. Segundo histórico clínico após realizado o tratamento, o paciente obteve melhora. Após cinco dias de alta clínica, o paciente retornou para atendimento apresentando piora abrupta do quadro. Em decorrência do grave estado clínico, optou-se pela eutanásia, e o cadáver foi encaminhado para a necropsia. Macroscopicamente, constatou-se moderado espessamento da pele, com oclusão do canal auditivo externo e secreção de coloração amarelada em ouvido direito (otite crônica). No hemisfério parietal e temporal direito e no assoalho encefálico havia um coágulo focalmente extenso moderado que comprimia o tecido nervoso. Notava-se também a presença moderada pus na bula timpânica direita. Microscopicamente, observou-se no córtex encefálico, meningite com perivasculite linfohistioplasmocitária, hiperemia acentuada, necrose focalmente extensa acentuada, além de presença de células inflamatórias polimorfonucleares e fibrina. Os achados macroscópicos e microscópicos são compatíveis com meningoencefalite, em decorrência da extensão de uma otite interna. A otite interna resulta da extensão da otite média, a qual pode ocorrer com ou sem osteomielite da parte petrosa do osso temporal. Com o tempo e a gravidade, as lesões progridem de forma retrógrada através do meato acústico interno em direção à cavidade craniana, resultando em meningite, ventriculite e encefalite (ZACHARY, 2018). Portanto, as otites internas devem ser consideradas como diferencial em casos de alterações neurológicas.

Palavras-chave: canino; meningite; osteomielite

\section{Referências}

SANTOS, L. R; ALESSI, C. A. Patologia Veterinária. 2 ed. Rio de Janeiro: Rocca, 2016.

ZACHARY, J.E. Bases da Patologia Veterinária. 6 ed. Rio de Janeiro: Elsevier, 2018. 